\title{
Morpho-anatomical characterization of Rhizopogon himalayensis - Cedrus deodara mycorrhiza
}

\author{
Gunjan Thakur* \\ Himalayan Forest Research Institute, Conifer Campus, Panthaghatti, Shimla -171013 \\ (Himachal Pradesh), India

\section{K. S. Kapoor} \\ Himalayan Forest Research Institute, Conifer Campus, Panthaghatti, Shimla -171013 \\ (Himachal Pradesh), India \\ Ashwani Tapwal \\ Himalayan Forest Research Institute, Conifer Campus, Panthaghatti, Shimla -171013 \\ (Himachal Pradesh), India \\ ${ }^{*}$ Corresponding author. Email: gunjan08thakur@gmail.com
}

\section{How to Cite}

Thakur, G. et al. (2021). Morpho-anatomical characterization of Rhizopogon himalayensis - Cedrus deodara mycorrhiza. Journal of Applied and Natural Science, 13(2), 668 - 676. https://doi.org/10.31018/jans.v13i2.2674

\begin{abstract}
Rhizopogon himalayensis (Castellano, S.L. Miller, Singh \& Lakhanpal) A.B. Mujic \& M.E. Sm., comb. nov. -an edible truffle-like fungus- normally exists in a symbiotic association with Cedrus deodara (Roxb.) Loud. Because of this important association and the ecological significance as per the available literature attached to this fungus, the present study was undertaken with a specific objective to test the mycorrhizal viability of this mycobiont with this important tree species of Himalaya -the theme tree of Himachal Pradesh. An attempt to investigate and record morphological and anatomical characteristics and variations in this mycorrhizal association was also made in nursery conditions using pure culture (wheat grain spawn) of $R$. himalayensis. The seedlings grown and inoculated in the nursery were harvested after six months for further examination, including the microscopic details. The study and subsequent analysis revealed that that mycobiont had invaded most of the feeder roots, imparting a typical swollen appearance to the mycorrhizal root tips. These root tips were light ochre with moderately thick plectenchymatic fungal mantle with occasional clamp connections on the inner layer of the fungal mantle. The root surface, as seen, was found smooth and frequently covered with a loose aggregation of inter-woven hyphae that uniformly pervaded the epidermis extending into the inter-cortical spaces of outer cortical cells and formed a characteristic Hartig net. Thus, results obtained in fact for the first time, presented an in-depth analysis of the morphological and anatomical characteristics of $R$. himalayensis and $C$. deodara association.
\end{abstract}

Keywords: Cedrus deodara, Ectomycorrhiza, Hyphae, Morpho-anatomy, Rhizopogon himalayensis.

\section{INTRODUCTION}

Rhizopogon is one of the genus of ectomycorrhizal basidiomycetic fungi and is characterized by hypogeous or sub-hypogeous fructifications consisting of one or two layered peridium engulfing gleba of locules without an internal columnella. It is fairly a large genus comprising an estimated $200+$ species, with a worldwide distribution. Rhizopogon species are mostly found in ectomycorrhizal association with the members of Pinaceae family and are prevalent symbionts of Douglas fir, pine and fir trees (Molina and Trappe, 1994; Allen et al., 1999; Molina et al., 1999; Grubisha et al., 2001, 2002,
2005; Dowie et al., 2011; Mujic et al., 2014, 2019). Studies on the related aspects as made in the past and the ongoing studies reflected that many species of the genus Rhizopogon predominantly exhibited strict host specificity showing exclusive association with a single host genus.

The importance of artificial mycorrhization using Rhizopogon species in re-forestation and rehabilitation of degraded forest areas have been thoroughly investigated (Castellano, 1996; Parlade et al., 1999; Pera et al., 1999; Steinfeld et al., 2003; Barroetavena et al., 2016) elsewhere and series of studies in-fact have documented the beneficial role of Rhizopogon species in enhanc- 
ing survival and growth of host plants (Parlade et al., 1999; Amaranthus et al., 2005; Rincon et al., 2007; Ducic et al., 2008). Some of the past studies have also shown that ectomycorrhizal associations with Rhizopogon species specifically improved resistance of plants in disturbed and fire- affected forest habitat (Miller et al., 1992; Taylor and Bruns, 1999; Peayet al., 2009; Sousa et al., 2012; Glassman et al., 2016; Day et al., 2020). Besides, several Rhizopogon species are valued and relished as supplementary food/food supplements by the natives across the world. A prominent example is $R$. roseolus (commonly known as Shoro), which is considered as a culinary delicacy in East Asia and Japan (Visnovsky et al., 2010, Yamada et al., 2017).

In India, Rhizopogon species have been mostly reported from Assam, Himachal Pradesh, and Jammu \& Kashmir. They are primarily represented by Rhizopogon guzmanii, $R$. luteolus, $R$. rosealus, $R$ sublateritius, $R$. villosulus, $R$. vulgaris and a recently discovered species R. himalayensis (Mujic et al., 2019). Though there is substantial literature available on Rhizopogon species diversity and distribution from India (Singh, 1992; Lakhanpal, 1996; Sharma et al., 2009; Beig et al., 2011; Kumar and Sharma, 2011; Chauhan et al., 2014; Malik et al., 2017; Paul et al., 2019; Singh and Passari, 2019 ; Suneja et al., 2019), yet studies about in vitro synthesis of Rhizopogon species, ectomycorrhizae are limited (Mohan et al., 1993, Reddy and Natarajan, 1996, Singh et al., 2020). As far as the mycorrhizal characterization aspect is concerned, not much has been reported/ documented. The detailed anatomical description is restricted to $R$. luteolus and Pinus patula association (Mohan et al., 1993). It is quite apparent that limited research pertaining to Rhizopogon species had been carried out so far in India, which might be due to insufficient sampling owing to its inconspicuousness and subterranean habit.

The specific focus of the present study is, therefore, on $R$. himalayensis, which is relatively a newly recorded species as also mentioned earlier and fruits exclusively in association with $C$. deodara in Himachal Pradesh, India (Castellano et al., 2012).

The present attempt will further expand and supplement existing information concerning this species. The study has been conducted on specific details like testing the ability of $R$. himalayensis to form mycorrhiza with seedlings of $C$. deodara under nursery conditions and documentation of morphological and anatomical features of its ectomycorrhizal association with C. deodara.

\section{MATERIALS AND METHODS}

The material used and the methodology adopted in the present study included seeds of $C$. deodara and the pure culture of $R$. himalayensis. Details of steps fol- lowed to accomplish the study can be explained as under:

\section{Seed collection and sterilization}

Seeds of C. deodara were collected in the month of October from Shillaru and Narkanda forests in the Shimla district of Himachal Pradesh. Healthy seeds were separated and thoroughly rinsed several times for few minutes under running tap water. Subsequently, the seeds were soaked in mild detergent solution and were washed again under running tap water till the removal of detergent. After this, seeds were surface sterilized by immersing them in 30 per cent solution of $\mathrm{H}_{2} \mathrm{O}_{2}$ (Hydrogen Peroxide) followed by repeated rinsing with sterile deionized water.

\section{Preparation of fungal inoculum}

Pure culture of $R$. himalayensis, was isolated from the inner tissues of its basidiocarp (Fig. 1A) as collected from C. deodara forests of Shillaru/ Narkanda falling in Shimla district of Himachal Pradesh during October forest and maintained on Potato Dextrose Agar medium at $21 \pm 2$. The culture was also deposited with $\mathrm{Na}$ tional Type Culture Collection (NTCC), Forest Research Institute under Accession no. NTCC 1261.

\section{Mass inoculum production}

For artificial inoculation of $C$. deodara seeds under nursery conditions, mass inoculum was produced on wheat grains (Fig. 1B). Wheat grains were earlier soaked in water overnight and later boiled till the grains seemed soft and succulent. About $9 \mathrm{~kg}$ of boiled wheat grains were air-dried for few hours, mixed with $120 \mathrm{~g}$ of gypsum (Calcium Sulphate, $\mathrm{CaSO}_{4}$ ) and $30 \mathrm{gm}$ of lime (Calcium carbonate, $\mathrm{CaCO}_{3}$ ) to adjust its $\mathrm{pH}$ and prevent clumping of grains.

Later, an approximate quantity (150-200 gm per bag) of these boiled grains were filled in poly propylene bags, plugged with non-absorbent cotton and autoclaved at $15 \mathrm{psi}\left(121^{\circ} \mathrm{C}\right)$ for 2 hours. Sterilized bags after cooling were inoculated with four to five $8 \mathrm{~mm}$ mycelial discs from the edges of actively growing fungal colony. Bags were then gently shaken to ensure even distribution of inoculum and incubated at $21 \pm 2^{\circ} \mathrm{C}$. The regular monitoring showed that the spawn got ready for subsequent inoculation within two to three weeks and at the same time also ensured the immediate removal of bags if these got contaminated.

\section{Artificial mycorrhizal inoculation}

Soil from the natural zone of $C$. deodara forest was taken, sieved through an ordinary wire mesh, and autoclaved before filling in nursery poly bags. Nursery bags were later filled with soil up to two-thirds of their capacity and the upper $1 / 3^{\text {rd }}$ portion of nursery bags was filled with autoclaved soil incorporated with grain spawn in a 
proportion of 1:10 (inoculum: substrate) (Hortal et al., 2009). It was followed by the immediate sowing of $C$. deodara seeds. This whole process of inoculation was carried out and accomplished in the month of November, 2016.

\section{Morpho-anatomical characterization of mycorrhizal roots}

Six months old seedlings of $C$. deodara growing in the nursery condition were uprooted and the root systems washed thoroughly under running tap water to remove any adhering particles/debris. Fungal colonization and morphology of mycorrhizae was examined under Stereo Zoom Microscope (Nikon-SMZ1500). Transverse sections of mycorrhizal root and examined at 10x, 40x and 100x magnifications under a Light Microscope (Nikon Eclipse-E200).

The surface-sterilized lateral root tips from nursery bags were inoculated onto Potato Dextrose Agar plates and compared with the initial culture of $R$. himalayensis isolated from its basidiocarp to confirm the fungal colonization on the host roots,.

\section{RESULTS}

When measured, the mean shoot height of six months old seedlings of $C$. deodara was recorded to be 21.17 $\mathrm{cm}$. The microscopic examination showed that the mycobiont had invaded most of the feeder roots, thereby imparting a swollen appearance to the ectomycorrhizal root tips. The ectomycorrhiza was found emerging as a lateral outgrowth from the mother root (Fig. 3C), displaying two distinct root morphologies, i.e., bulbous short roots of limited growth and the long tapering roots. The branching pattern recorded was usually monopodial-pinnate to coralloid type (Fig. 3A). Emanating hyphae were seen aggregating around root hair which upon further proliferation suppressed root hair development. The appearance of root hair also changed drastically as they became twisted or coiled up and subsequently collapsed with the progress of hyphal invasion (Fig. 2 A-E). The fungal hyphae penetrated between epidermal cells (Fig. 4) and formed a highly branched structure, referred to as Hartig net: an interface between the fungal hyphae and the host plant. Morphological and anatomical characteristics of the ectomycorrhiza as studied and described following the key provided by "An Information System for Characterization and Determination of Ectomycorrhizae" (DEEMY, homepage: http:// www.deemy.de/) (Agerer, 1991).

\section{Morphological features}

Detailed microscopy and subsequent analysis of morphological features of this mycobiont revealed that the roots were monopodial-pinnate to coralloid with the ramification of $0-3$ order and hydrophilic. The roots were $5-17 \mathrm{~mm}$ in length and $0.5-1 \mathrm{~mm}$ thick. The fungal mantle have been found not unsheathing the roots completely but was restricted only to its distal ends. A fungal mantle completely encircled the root ends and the root hair development was suppressed altogether. In contrast to this observation, the proximal root-ends were entirely devoid of the fungal mantle and was found to be covered with abundant root hair. The color of mycorrhizal roots varied from ochre or dull brown to dark brown (Fig.s 2 and 3). The root surface, although smooth, was frequently covered with the loose aggregation of inter-woven and emanating hyphae as well. The soil particles were usually found adhering to the roots.

Fungal mantle was light brown to dark brown in color, causing partial obscuring of the host tissues and the surface was shiny and smooth (Fig.s 4B and 4D). Development was found restricted to the root tips during early stages of colonization but complete encasing of the entire root length was observed over a period of time. The thickness of mantle varied from thin and later segregated to moderately thick and finally regular in mature roots.

Short roots measured up to $4 \mathrm{~mm}$ long, $1 \mathrm{~mm}$ wide with apices varying from $0.30-0.6 \mathrm{~mm}$ in length and 0.2 $0.35 \mathrm{~mm}$ in width and the color of the tips was found changing from pale yellow to brown or deep brown at maturity. The shape was sinuous to tortuous and the apices were club-shaped or inflated as compared to un -infected root tips. The surface of the roots was smooth with a shiny to matte appearance.

Long roots were also found mycorrhizal in nature although fungal mantle was comparatively thin in the instant case. The color of the root tip was creamish or off white to pale yellow and were straight or slightly bent with tapering apices. The root hair development when observed was significantly reduced and the host tissues were often seen breaking through the fungal mantle near the apical region. The fungal mantle was usually seen to be patchy or segregated.

Emanating hyphae (Fig.s 3B and 3C) when studied in detail it was found smooth and were elongated up to $400 \mu \mathrm{m}$ long. These hyphae were thin-walled with hyphal width varying from $0.4-2$ or $1.5-3.0 \mu \mathrm{m}$ in diameter, hyaline to turning dull brown at the later stages. The shape was even and straight, ramification was frequent with approximately right-angled to y-shaped branches, hyphae were recorded as septate (Fig. 4A) but without clamp connections. They were usually concentrated in bundles at proximal ends but sparsely distributed towards apices

Mycelial strands were found quite infrequent, with their diameter varying from 10-14 $\mu \mathrm{m}$, hyaline with narrowangle to the root axis. The constituent hyphae were parallel and densely aggregated with margin smooth to 

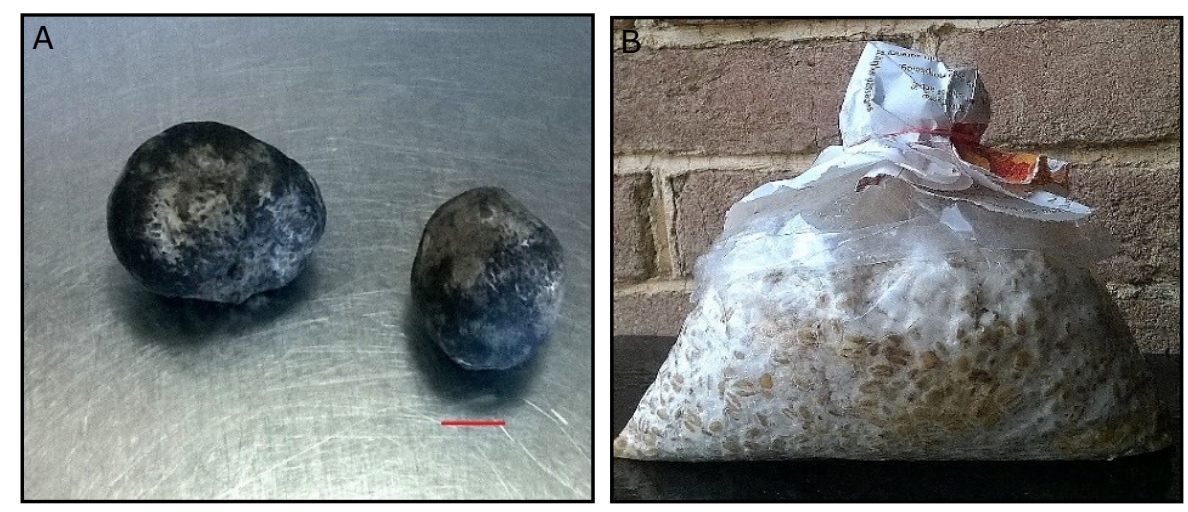

Fig.1. A. Basidiocarps of R. himalayensis, Scale $=10 \mathrm{~mm}$ B. Wheat grain spawn of $R$. himalayensis $C$. $R$. himalayensis tailored $C$. deodara seedling harvested from nursery bags, Scale $=2 \mathrm{~cm}$.

occasional hyphae protruding along the length. Rhizomorphs however, were found absent.

\section{Anatomical features}

Anatomically, root association of this fungus exhibited typical ectomycorrhizal anatomy with mantle thickness varying from 10 to $20 \mu \mathrm{m}$ in the newly colonized root and subsequently reaching up to $50 \mu \mathrm{m}$. The mantle colour was ochre to deep dark brown (Fig. 4B and 4D). The surface was found quite smooth with fine, sparsely placed, or loosely inter-woven hyphae at times radiating in the extra-matrical phase. The mantle formation was mostly continuous and the mycobiont encircled the root tips completely, but few sections also displayed patchy or segregated mantle. Mantle was plecten-chymatous throughout and the hyphal uniformly pervaded the epidermis, infecting the inter-cortical spaces of outer cortical cells and forming a characteristic Hartig net.

In the outer mantle, hyphae were quite thin with 0.2-0.5 $\mu \mathrm{m}$ in diameter, loosely aggregated in several rows, ochre to medium brown in colour, septate and the clamp connections were absent (Fig. 4D). Hyphal septations were also not discernible.

In the inner mantle (Fig. 4D), hyphae were also thinner with their thickness varying from 0.1-0.3 $\mu \mathrm{m}$. These hyphae were long, compact and parallelly arranged, the color was deep brown. Branching was common, and septation was frequent with occasional clamp connections.

Epidermal cells were primarily tangentially-oval to tangentially-elliptic (Fig. 4) and became progressively compressed and flattened along the radial axis (Fig. $4 \mathrm{C}$ and 4D). Radial thickness showed a range of $20-45 \mu \mathrm{m}$ in case of moderate infection and 4-18 $\mu \mathrm{m}$ in high infection and tangential length varied from $25-80 \mu \mathrm{m}$. During heavy infection, the epidermis became completely absorbed in the mantle.

Hartig net was found quite prominent, having two corti- cal cell rows deep but somehow, not reaching endodermis (Fig. 4). However, in some areas which were heavily infected Hartig net was found extending towards endodermis. Some of the cells were found angular and rounded at times mainly in young root tips but became modified to tangentially elliptic in older root tips due to Hartig net formation. Radial diameter of these cells commonly known as Cortical cells was found varying in between $25 \mu \mathrm{m}$ to $60 \mu \mathrm{m}$ and their tangential length varied between $20 \mu \mathrm{m}-70 \mu \mathrm{m}$. The hyphae between the inter-cortical cell were three to several rows thick during heavy mycorrhizal infection.

Endodermis and Stele seemed mostly free of mycorrhizal infection whereas, the Tannin cells were frequent and were found restricting to the epidermal or outer cortical cells and the shape was rounded to elliptical or at times found oblong. The comparison of fungal culture isolated from the $C$. deodara root tips with the original culture of $R$. himalayensis revealed the identical cultural characteristics, i.e. cottony dull-white colony with septate hyphae and devoid of clamp connections thereby, confirming to the identity of this mycobiont.

\section{DISCUSSION}

In a nutshell, the results of the present study revealed that the association formed between $R$. himalayensis and $C$. deodara under nursery conditions was truly ectomycorrhizal with a well-developed mantle and the Hartig net.

The observations of the current study have been scrutinized, bearing in mind an earlier study on $R$. himalayensis-C. deodara association (Singh, 1992) and largely in the light of morpho- anatomical descriptions of other Rhizopogon species associations with members of the family Pinaceae.

The root hair and hyphal interaction in the current study were found to be similar to what was observed in Quer- 

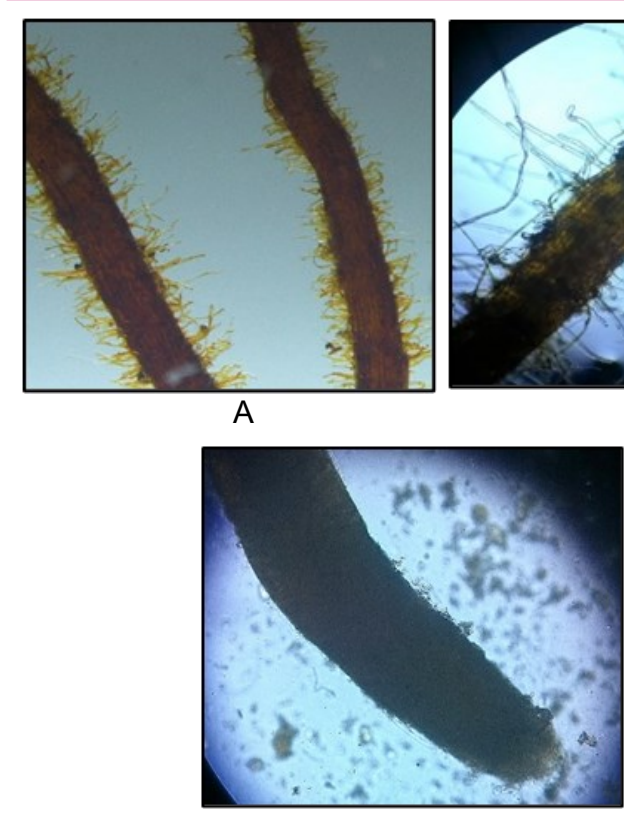

E

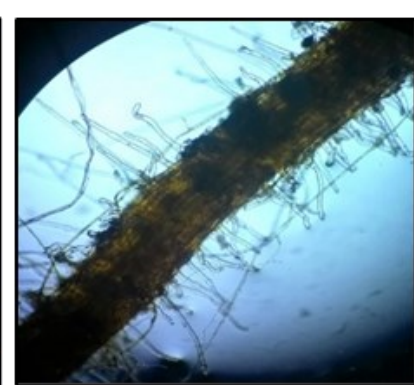

B

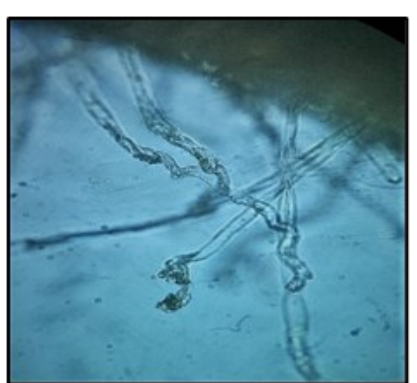

C

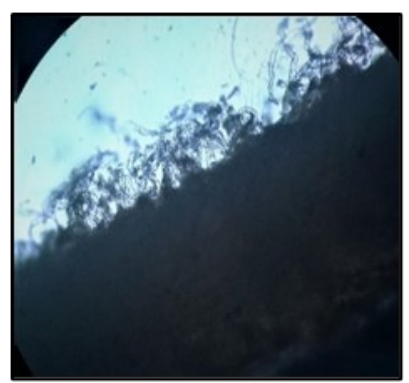

D

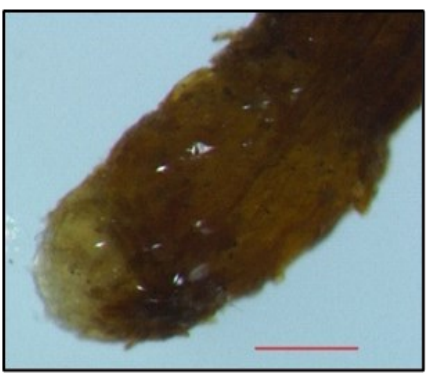

$\mathrm{F}$

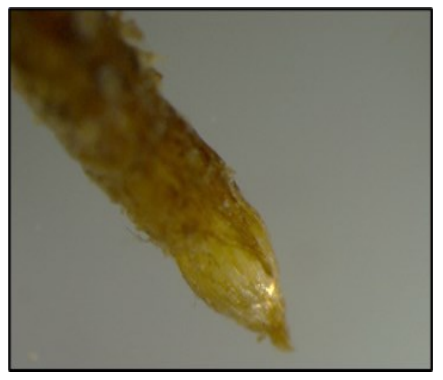

G

Fig. 2: Interaction between hyphae and root hair during mantle development $A$ - I: A. Intact root hair before fungus colonization, B. Initiation of encasing of root hair by aggregation and proliferation of hyphae, $C$. Subsequent twisting (arrow heads) and collapse of root hair with further penetration of fungal hyphae, D. Further deformation and suppression of root hair, E. Complete incorporation of root hair within fungal mantle, F. Inflation of mycorrhizal root tip, Scale= $1 \mathrm{~mm}$ G. Root tissue projecting through fungal mantle in long root.

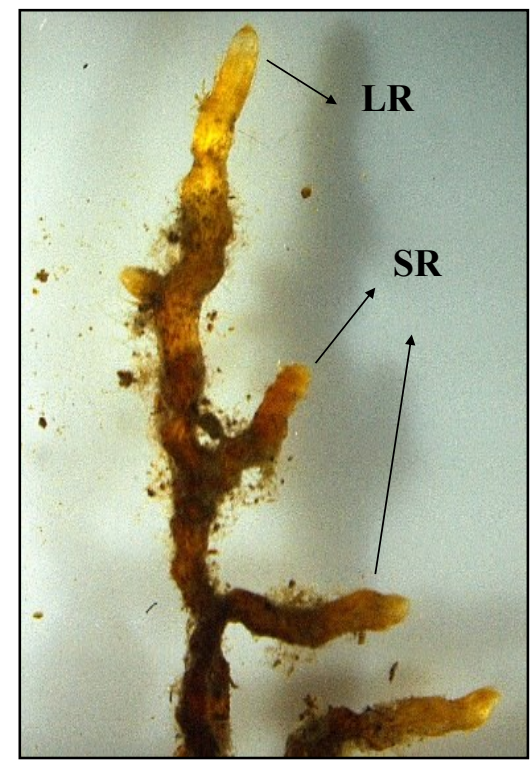

A

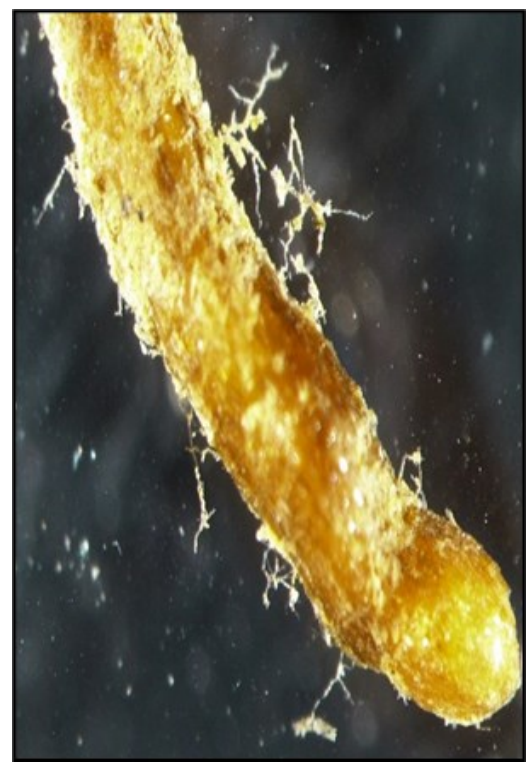

B

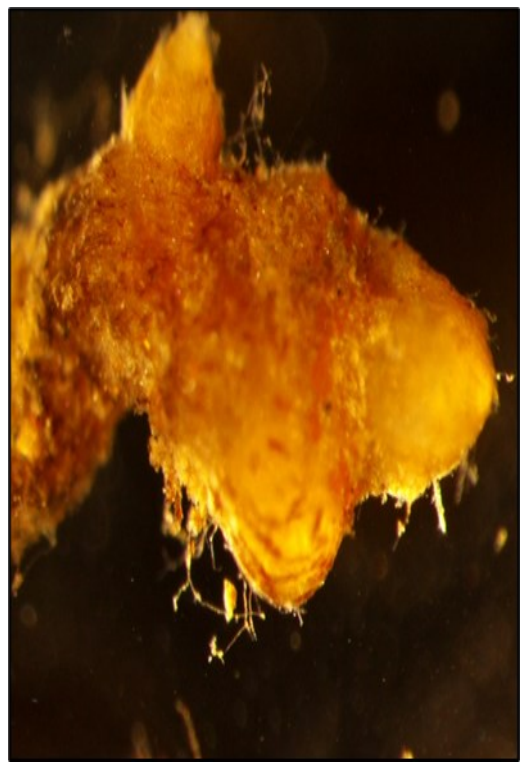

C

Fig. 3. Morphological structure of ectomycorrhiza of R. himalayensis- C. deodara, A. Monopodial- pinnate mycorrhizal root showing long and short roots, $\boldsymbol{B}$. Loosely aggregated extrametrical hyphae radiating from root, $\boldsymbol{C}$. Emerging lateral root, Abbreviation, $L R=$ Long root, $S R=$ Short root.

cus acutissima-Scleroderma verrucosum mycorrhizae (Jung and Tamai, 2012). In both systems, hyphal contact induced significant modifications in root hair structure, causing deformation and subsequent incorporation of root hair in the fungal mantle. On the contrary, in Betula alleghaniensis- Laccaria bicolor (Massicotte et al., 1989) and Pseudotsuga menziesii-R. parksii mycor- rhiza (Massicotte, 2000), hyphal contact caused wall thickening in root hair, preventing the collapse of root hair.

Colour had also been found as an important feature while describing ectomycorrhizal morphology (Zak, 1973; Agerer et al., 1986) and which also showed variations with the advancement of age of mycorrhiza (Haug and Oberwinkler, 1987). A similar pattern was 

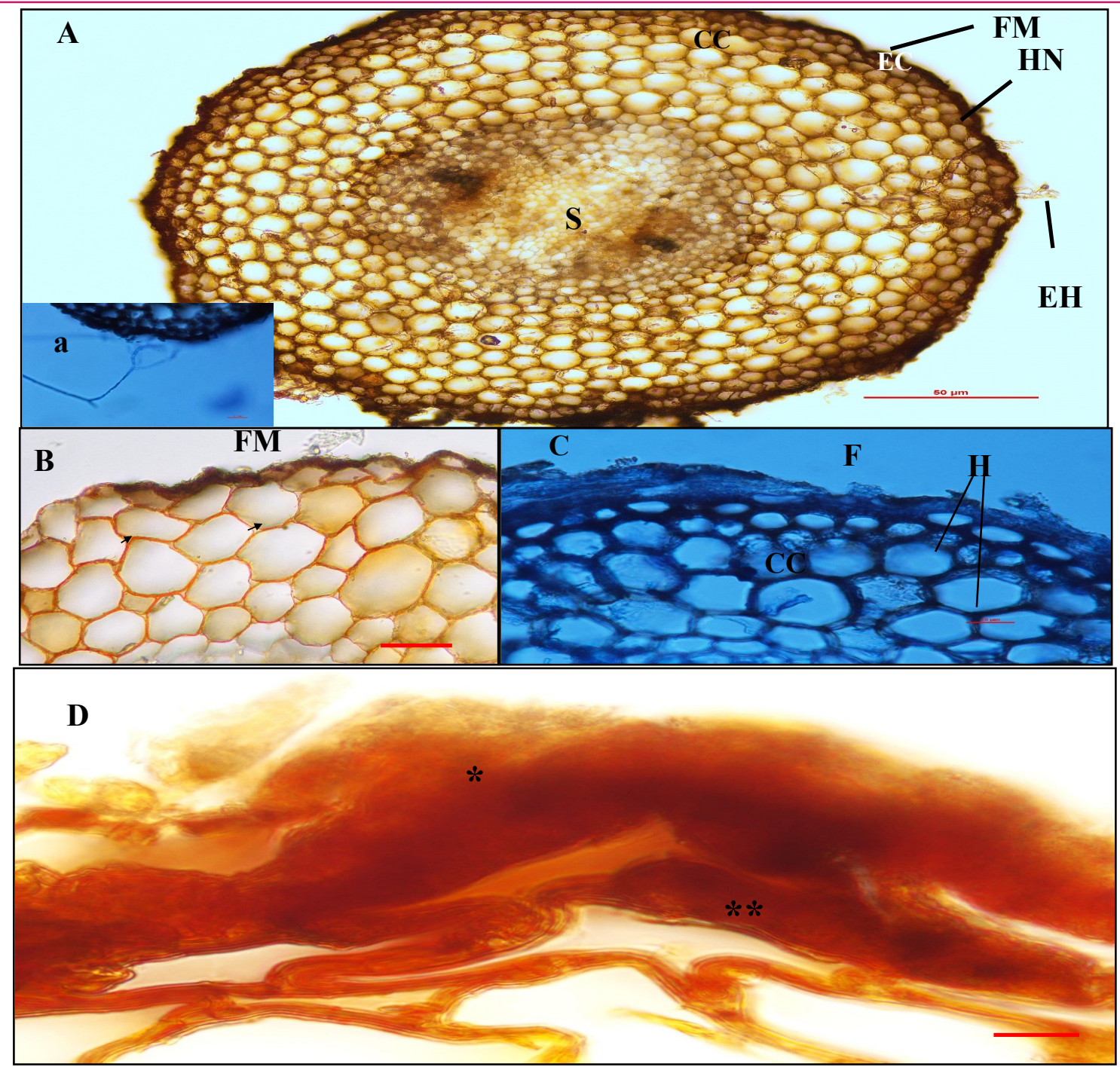

Fig. 4. A. Transverse section of $C$. deodara root, a. Septate hypha extending from the mantle (400x) B. Unstained transverse section showing fungal mantle in initial stages of development and inter cellular space between slightly angular cortical cells (double head arrow), (400x), Scale $=50 \mu \mathrm{m}$. C Lactophenol cotton blue stained section showing well developed fungal mantle and prominent Hartig net reaching inner cortical cells (400x), Scale $=10 \mu m \boldsymbol{D}$. Fungal mantle in high resolution showing inner mantle $\left(^{*}\right)$, and outer mantle ${\left({ }^{* *}\right)}^{*},(1000 x)$, Scale $=50 \mu m(A), 10 \mu m\left(A_{1}, B, C, D\right)$ (Abbreviations, $E M=$ Extrametrical hyphae, $F M=$ Fungal Mantle, $O M=$ Outer mantle, $I M=I n n e r$ mantle, $H N=H a r t i g ~ N e t$, $M=$ Mycorrhizal root tips, $C C=$ Cortical cell, EC= Epidermal cell, $S=$ Stele).

also noticed in the present study as well, wherein the color of ectomycorrhiza transitioned from initial dull white or pale yellow through ochre to dark brown at maturity.

In the present study, root morphology in ectomycorrhiza of $R$. himalayensis and $C$. deodara roots was found to be analogous to the observations of Singh (1992), who noticed racemose to coralloid branching in this association. Similar branching was illustrated in various mycorrhizal associations of Rhizopogon species, for instance, coralloid in R. vulgaris- Pinus contorta (Molina and Trappe, 1994; Agerer et al., 1996); monopodial to dichotomous in $R$. subcaerulescens - Pseudotsuga menziesii (Massicotte et al., 1999); pinnate in $R$. vinicolor and $R$. parksii with $P$. menziesii (Massicotte, et al., 2000). Although, different root morphologies have also been reported in other Rhizopogon species, i.e. tuberculate in $R$. truncates - Tsuga mertensian (Zak, 1971); tuberculate clusters in Rhizopogon vinicolorPseudotsuga menziesii association (Massicotte et al., 1992, 1994, Molina and Trappe, 1994).

In the present study it was also observed that the hyphal mantle underwent considerable variations as the colonization progressed like an initially thin and segregated mantle was replaced by a regular uniform mantle with two distinct layers of the different hyphal constitution: thinner and compacted hyphae in inner mantle relative to loosely aggregated hyphae in the outer mantle. Present observations are in analogy with the findings of a previous study that described two-layered 
mantle in case of $R$. arctostaphyli, $R$. smithii and $R$. subcaerulescens ectomycorrhizas synthesized on Pinus ponderosa in a glasshouse condition (Massicotte et al., 1999). Similarly, a two-layered mantle with loosely interwoven hyphae in outer mantle and compacted hyphae in inner mantle was seen in ectomycorrhiza of $R$. rubescens-Pinus sylvestris (Pachlewski and Pachlewska, 1974). Similar mantle arrangement and hyphal morphology was observed in R. luteolus on Pinus sylvestris (Uhl, 1988).

However, many dissimilarities have been seen in ectomycorrhizas of other Rhizopogon species and plant species associations. For instance, a definite fungal mantle organized into three layers was observed in ectomycorrhiza of $R$. verii growing under Pinus sylvestris (Sulzbacher et al., 2016). In another example, a thin and undifferentiated mantle was observed in $R$. ellenae and $R$. rubescens ectomycorrhiza on Pinus ponderosa (Massicotte et al., 1999). In most of the ectomycorrhizal associations of Rhizopogon species with Pinus ponderosa as well as in R. parksii- Pseudostuga, the hyphal mantle was plectenchymatous and clamp connections were absent in mantle hyphae or emanating elements (Massicotte et al., 1994). In the same way, emanating hyphae were found devoid of clamp connections in $R$. vinicolor and $P$. densiflora (Yamada, 2001). Much like these, the present study also showed the complete absence of clamp connections in the emanating hyphae of $R$. himalayensis- $C$. deodara association, although, occasional hyphal clamps were encountered in the inner mantle layer.

In a comprehensive account of ectomycorrhizae formed by Rhizopogon species, most of the Rhizopogon species exhibited loosely woven outer mantle and Hartig net extending up to 4 cortical cell layers (Molina and Trappe, 1994). Present findings, hence, corroborates with their observations, strongly resonating with their descriptions of $R$. vulgaris-Pinus contorta association (loose hyphae at surface and compact on the inner side) in particular.

Many species of Rhizopogon- are known to produce prolific, dark brown rhizomorphs (Massicotte, 1994, 2000; Yamada, 2001). R. himalayensis- C. deodara association in nature too is characterized by concolorous, stout rhizomorphs (Castellano et al., 2012). On the contrary, present investigation in the nursery condition recorded the complete absence of rhizomorphs. Although, microscopic examination of ectomycorrhiza of $R$. himalayensis and C. deodara revealed infrequent mycelial chords extending from the root surface. Therefore, from the findings of the present study, it can easily be inferred that morphological contrasts with respect to certain features may vary with different environmental conditions for the same set of ectomycorrhizal associating partners. It is apparent from this study and the relevant supporting literature that fungal partner plays a crucial role in shaping the morphology and structure of ectomycorrhizae.

\section{Conclusion}

The present study shows that the association formed between R. himalayensis and C. deodara under nursery conditions is truly ectomycorrhizal with a welldeveloped mantle and a Hartig net. The root morphology was noted to be monopodial-pinnate to coralloid branching in this association. The root hair and hyphal interaction was further noted to induce significant changes in root hair structure, causing deformation and subsequent incorporation of root hair in the fungal mantle. It was observed that the hyphal mantle underwent considerable variations as the colonization progressed from an initially thin and segregated mantle to a regular uniform mantle. The hyphal mantle was constituted of two distinct layers: thinner and compacted hyphae in the inner mantle and loosely aggregated hyphae in the outer mantle. The Hartig net was noted to be prominently two cortical cell rows deep, not reaching endodermis, except in some areas of heavy infection. Furthermore, the endodermis and stele seemed mostly free of mycorrhizal infection. Present findings with special reference to the morphological and anatomical characterization of $R$. himalayensis- $C$. deodara are significant as these will pave the way for facilitating accurate identification of fungus-host association in future studies. Henceforth, it indicates that further studies are essentially required to ascertain the performance of the $C$. deodara seedlings through periodic analysis of relevant growth parameters.

\section{Conflict of interest}

The authors declare that they have no conflict of interest.

\section{REFERENCES}

1. Agerer, R. (1986). Studies on ectomycorrhizae. II: Introducing remarks oncharacterization and identification. Mycotaxon, 26, 473-492

2. Agerer, R. (1991). Characterization of Ectomycorrhiza. Methods in microbiology, Academic Press, pp 25-73, https://doi.org/10.1016/s0580-9517(08)70172-7.

3. Agerer, R., Muller, W. R. \& Bahnweg, G. (1996). Ectomycorrhizae of Rhizopogon subcaerulescens on Tsuga heterophylla. Nova Hedwigia, 63(3), 397-416

4. Allen, M. F., Trappe, J. M. \& Horton, T. R. (1999). NATS Truffle and truffle-like fungi Rhizopogonmengei sp. nov. (Boletaceae, Basidiomycota). Mycotaxon, 70,149-152

5. Amaranthus, M. P., Nair, M. G., Reid, T. C. \& Steinfeld, D. (2005). Improved Rhizopogon mycorrhizal colonization and foliar nutrient levels in Ponderosa pine and Douglasfir with myconate (r). Journal of Sustainable Forestry, 20 (3),1-14, https://doi.org/10.1300/j091v20n03_01.

6. Barroetavena, C., Bassani, V. N., Monges, J. I. \& Rajch- 
enberg, M. (2016). Field performance of Pinus ponderosa seedlings inoculated with ectomycorrhizal fungi planted in steppe grasslands of Andean Patagonia, Argentina. Bosque, 37(2), 307-316, https://doi.org/10.406 7/s0717-92002016000200009

7. Beig, M. A., Dar, G. H., Khan, N. A. \& Ganai, N. A. (2011). Seasonal production of epigeal fungal sporocarps in mixed and pure fir (Abies pindrow) stands in Kashmir forests. Journalof Agricultural Technology, 7(5),1375-1387

8. Castellano, M. A. (1996). Outplanting performance of mycorrhizal inoculated seedlings. Concepts in mycorrhizal research. Springer, Dordrecht, pp 223-301, https:// doi.org/10.1007/978-94-017-1124-1_9

9. Castellano, M. A., Miller, S. L., Singh, L. \& Lakhanpal, T. N. (2012). Trappeindia himalayensis gen. et $\mathrm{sp}$. nov., a sequestrate fungus with potential affinity to Strobilomyces (Basidiomycotina, Boletales). KAVAKA, 40, 3-5

10. Day, N. J., Cumming, S. G., Dunfield, K. E., Johnstone, J. F., Mack, M. C., Reid, K. A. \& Baltzer, J. L. (2020). Identifying Functional Impacts of Heat-Resistant Fungi on Boreal Forest Recovery After Wildfire. Front. For. Glob. Change, 3, 68, https://doi.org/10.26686/wgtn.143 30717

11. Dowie, N. J., Hemenway, J. J., Trowbridge, S. M. \& Miller, S. L. (2011). Mycobiont overlap between two mycoheterotrophic genera of Monotropoideae (Pterospora andromedea and Sarcodes sanguinea) found in the Greater Yellowstone Ecosystem. Symbiosis, 54(1), 29-36, https:// doi.org/10.1007/s13199-011-0127-1

12. Ducic, T., Parlade, J. \& Polle, A. (2008). The influence of the ectomycorrhizal fungus Rhizopogon subareolatus on growth and nutrient element localisation in two varieties of Douglas fir (Pseudotsuga menziesii var. menziesii and var. glauca) in response to manganese stress. Mycorrhiza, 18(5), 227-239, https:// doi.org/10.1007/s00572-008-0174-5

13. Glassman, S. I., Levine, C. R., DiRocco, A. M., Battles, J. J. \& Bruns, T. D. (2016). Ectomycorrhizal fungal spore bank recovery after a severe forest fire: some like ithot. The ISME journal, 10(5),1228-1239, https://doi.org/1 0.1038/ismej.2015.182.

14. Grubisha, L. C., Trappe, J. M., Molina, R. \& Spatafora, J. W. (2001). Biology of the ectomycorrhizal genus Rhizopogon. V. Phylogenetic relationships in the Boletales inferred from LSU rDNA sequences. Mycologia, 93(1), 82-89, https://doi.org/10.1080/002 75514.2001.12061281.

15. Grubisha, L. C., Trappe, J. M., Molina, R. \& Spatafora, J. W. (2002). Biology of the ectomycorrhizal genus Rhizopogon. VI. Re-examination of infrageneric relationships inferred from phylogenetic analyses of ITS sequences. Mycologia, 94(4),607-619, https://doi.org/10.2307/3 7 61712

16. Grubisha, L. C., Trappe, J. M., Beyerle, A. R. \& Wheeler, D. (2005). NATS truffle and trufflelike fungi 12: Rhizopogon after sp. nov. and $R$. brunsii sp. nov. (Rhizopogonaceae, Basidiomycota). Mycotaxon, 93,345354.

17. Haug, I. \& Oberwinkler, F. (1987). Some distinctive types of spruce mycorrhizae. Trees, 1(3),172-188, https:// doi.org/10.1007/bf00193560

18. Jung, N. C. \& Tamai, Y. (2012). Ecological role and modification of the plant and fungal cell structure in the inter- face between host root and ectomycorrhizal hyphae. Mycology, 3(1),24-35

19. Kumar, S. \& Sharma, Y. P. (2011). Diversity of wild mushrooms from Jammu and Kashmir (India). In Proceedings of the 7th International Conference on Mushroom Biology and Mushroom Products (ICMBMP7), pp 568-77

20. Lakhanpal, T. N. (1996). Mushrooms of India, Boletaceae. APH Pub. Corp.

21. Lakhanpal, T. N. \& Singh, L. (2002). Cedrus deodara root rot disease- threat to the Himalayan forestry and environment. Indian Phytopathology, 53 (1),50-56

22. Malik, A. R., Wani, A. H., Bhat, M. Y. \& Parveen, S (2017). Ethnomycological knowledge of some wild mushrooms of northern districts of Jammu and Kashmir, India. Asian Journal of Pharmaceutical and Clinical Research, 10(9),399-405, https://doi.org/10.22159/ajpcr.201 7.v10i9. 17641

23. Massicotte, H. B., Peterson, R. L. \& Melville, L. H. (1989). Hartig net structure of ectomycorrhizae synthesized between Laccaria bicolor (Tricholomataceae) and two hosts: Betula alleghaniensis (Betulaceae) and Pinus resinosa (Pinaceae). American journal of botany, 76(11),16541667, https://doi.org/10.1002/j.1537-2197.1989.tb15150.x

24. Massicotte, H. B., Molina, R., Luoma, D. L. \& Smith, J. E. (1994). Biology of the ectomycorrhizal genus, Rhizopogon: II. Patterns of host $\square$ fungus specificity following spore inoculation of diverse hosts grown in monoculture and dual culture. New Phytologist, 126(4),677-690, https:// doi.org/10.1111/j.1469-8137.1994.tb02962.x

25. Massicotte, H. B., Melville, L. H., Peterson, R. L. \& Molina, R. (1999). Biology of the ectomycorrhizal fungal genus, Rhizopogon: IV. Comparative morphology and anatomy of ectomycorrhizas synthesized between several Rhizopogon species on Ponderosa pine (Pinus ponderosa). New Phytologist, 142(2), 355-370, ttps:// doi.org/10.1046/j.1469-8137.1999.00392.x

26. Massicotte, H. B., Melville, L. H., Peterson, R. L. \& Molina, R. (2000). Comparative anatomy of ectomycorrhizas synthesized on Douglas fir by Rhizopogon species and the hypogeous relative Truncocolumellacitrina. New Phytologist, 147(2), 389-400, https://doi.org/10.1046/j.14698137.2000.00700.x

27. Miller, S. L., Koo, C. D. \& Molina, R. (1992). Early colonization of red alder and Douglas fir by ectomycorrhizal fungi and Frankia in soils from the Oregon coastrange. Mycorrhiza, 2(2),53-61, https://doi.org/10.100 7/bf00203250

28. Molina, R. \& Trappe, J. M. (1994). Biology of the ectomycorrhizal genus, Rhizopogon: I. Host associations, hostspecificity and pure culture syntheses. New Phytologist, 126(4),653-675, https://doi.org/10.1111/j.1469-8137.1 994.tb02961.x

29. Molina, R., Trappe, J. M., Grubisha, L. C. \& Spatafora, J. W. (1999). Rhizopogon. Ectomycorrhizal fungi key genera in profile Springer, Berlin, Heidelberg, pp 129-161, https:// doi.org/10.1007/978-3-662-06827-4_5.

30. Mujic, A. B., Hosaka, K. \& Spatafora, J.W. (2014). Rhizopogon togasawariana sp. nov., the first report of Rhizopogon associated with an Asian species of Pseudotsuga. Mycologia, 106(1),105-112, https:// doi.org/10.3852/13-055

31. Mohan, V., Natarajan, K. and Ingleby, K. (1993). Anatomi- 
cal studies on ectomycorrhizas. Mycorrhiza, 3(1),43-49, https://doi.org/10.1007/bf00213467

32. Molina, R. \& Trappe, J. M. (1994). Biology of the ectomycorrhizal genus, Rhizopogon: I. Host associations, host specificity and pure culture syntheses. New Phytologist, 126(4), 653-675, https://doi.org/10.1111/j.1469-813 7.1994.tb02961.x

33. Mujic, A. B., Zheng, N., Kim, K., Spatafora, J. W., Castellano, M. A. \& Smith, M. E. (2019). The Cedrus-associated truffle Trappeindia himalayensis is a morphologically unique and phylogenetically divergent species of Rhizopogon. Mycologia, 111(2), 225- 234, https://doi.org/10.10 80/00275514.2018.1542864.

34. Pachlewski, R. \& Pachlewska, J. (1974). Studies on symbiotic properties of mycorrhizal fungi of pine (Pinus sylvestris L.) with the aid of the method of mycorrhizal synthesis in pure cultures on agar, $\mathrm{p} 228$

35. Parlade, J., Pera, J., Alvarez, I. F., Bouchard, D., Genere, B. \& Le Tacon, F. (1999). Effect of inoculation and substrate disinfection method on rooting and ectomycorrhiza formation of Douglas fir cuttings. Annals of forest science, 56(1), 35-40, https://doi.org/10.1051/forest:19990 105 .

36. Paul, M., Sarma, T. C. \& Deka, D. C. (2019). Macrofungal diversity of some districts of Assam, India with special reference to their uses. Asian Journal of Conservation Biology, 8(2), 115-125

37. Peay, K. G., Garbelotto, M. \& Bruns, T. D. (2009). Spore heat resistance plays an important role in disturbancemediated assemblage shift of ectomycorrhizal fungi colonizing Pinus muricata seedlings. Journal of Ecology, 97 (3), 537-547, https://doi.org/10.1111/j.1365-2745.200 9.01489.x

38. Pera, J., Alvarez I.F., Rincon, A. \& Parlade, J. (1999) Field performance in northern Spain of Douglas fir seedlings inoculated with ectomycorrhizal fungi. Mycorrhiza, 9, 7784, https://doi.org/10.1007/s005720050003

39. Reddy, M. S. \& Natarajan, K. (1996). In vitro ectomycorrhizal formation of Pinus patula, P.pseudostrobus, $P$. oocarpa and $P$. elliotii grown in southern India. New forests, 11(2), 149-153, https://doi.org/10.1007/bf00033410

40. Rincon, A., De Felipe, M. R. \& Fernandez-Pascual, M. (2007). Inoculation of Pinus halepensis Mill. with selected ectomycorrhizal fungi improves seedling establishment 2 years afterplanting in a degraded gypsum soil. Mycorrhiza, 18(1), 23-32, https://doi.org/10.1007/s00 57 2-007-0149-y

41. Sharma, S., Gautam, A. K. \& Bhadauria, R. (2009). Some important supplementary food plants and wild edible fungi of upper hilly region of district Shimla (Himachal Pradesh), India. Ethnobotanical Leaflets, 8, 6

42. Singh, L. (1992). Studies on the mycorrhizal relationships of Cedrus deodara \& Trappeinda himalayensis- a new edible mushroom from N.W. Himalayas. Himachal Pradesh University.

43. Singh, B. P. \& Passari, A. K. (2019). Biology of Macrofungi. Springer, https://doi.org/10.1007/978-3-030-02622-6

44. Singh, L. \& Lakhanpal, T. N. (2000). Growth and ectomycorrhiza development in Cedrus deodara seedlings inoculated with different vegetative inoculum formulations. Journal of Mycology and Plant Pathology, 30(1), 64-67

45. Singh, P. L., Tripathi, K., Yadav, R. B. \& Yadav, K. N. (2014). Devadaru (Cedrus deodara (Roxb.) Loud.: A criti- cal review on the medicinal plant. International Journal of Ayurveda and Pharma Research, 2, 110

46. Singh, Singh, L. Tapwal, A., Thakur, J.S. \& Lakhanpal, T. N. (2020). Studies on the nutritional requirement and in vitro synthesis of mycorrhiza of Cedrus deodara with Rhizopogon himalayensis. KAVAKA, 54, 2429, https://doi.org/10.36460/kavaka/54/2020/24-29

47. Sousa, N. R., Ramos, M. A., Marques, A. P. \& Castro, P. M. (2012). The effect of ectomycorrhizal fungi forming symbiosis with Pinus pinaster seedlings exposed to cadmium. Science of the Total Environment, 414,63-67, https://doi.org/10.1016/j.scitotenv.2011.10.053 .

48. Steinfeld, D., Amaranthus, M. P. \& Cazares, E. (2003). Survival of ponderosa pine (Pinus ponderosa Dougl. ex Laws.) seedlings outplanted with Rhizopogon mycorrhizae inoculated with spores at the nursery. Journal of Arboriculture, 29(4),197-208

49. Sulzbacher, M. A., Grebenc, T., García, M. A., Silva, B. D., Silveira, A., Antoniolli, Z. I., \& Martin, M. P. (2016). Molecular and morphological analyses confirm Rhizopogonveriiasa widely distributed ectomycorrhizal false truffle in Europe, and its presence in South America. Mycorrhiza, 26(5), 377-388, https://doi.org/10.1007/ s00572-015-0678-8

50. Suneja, G., Nain, S. \& Sharma, R. (2019). Microbiome: A Source of Novel Bioactive Compounds and Antimicrobial Peptides. Microbial Diversity in Ecosystem Sustainability and Biotechnological Applications. Soil \& Agroecosystems. Springer, pp 615-630, https://doi.org/10.1007/978981-13-8315-1_19.

51. Taylor, D. L. \& Bruns, T. D. (1999). Community structure of ectomycorrhizal fungi in a Pinus muricata forest: minimal overlap between the mature forest and resistant propagule communities. Molecular Ecology, 8(11), 1837-1850, https://doi.org/10.1046/j.1365-294x.1999.00773.x

52. Uhl, M. (1988) Studies on mycorrhizae. XV. Mycorrhizae formed by Rhizopogon luteolus on Pinus sylvestris. Persoonia, 13,449-458

53. Visnovsky, S. B., Guerin-Laguette, A., Wang, Y. \& Pitman, A. R. (2010). Traceability of marketable Japanese shoro in New Zealand: using multiplex PCR to exploit phylogeographic variation among taxa in the Rhizopogon subgenus Roseoli. Applied and environmental microbiology, 76(1), 294-302, https://doi.org/10.1128/aem.02191-09

54. Yamada, A., Ogura, T. \& Ohmasa, M. (2001). Cultivation of mushrooms of edible ectomycorrhizal fungi associated with Pinus densiflora by in vitro mycorrhizalsynthesis. Mycorrhiza, 11(2), 67-81, https://doi.org/10.1007/s00 5720000093

55. Yamada, A., Furukawa, H. \& Yamanaka, T. (2017). Cultivation of edible ectomycorrhizal mushrooms in Japan. Revista Fitotecnia Mexicana, 40(4),379-389, https:// doi.org/10.35196/rfm.2017.4.379-389

56. Zak, B. (1971). Characterization and classification of mycorrhizae of Douglas fir. II. Pseudotsuga menziesii+ Rhizopogon vinicolor. Canadian Journal of Botany, 49 (7),1079-1084, ttps://doi.org/10.1139/b71-154

57. Zak, B. (1973). Classification of ectomycorrhizae. Ectomycorrhizae: their ecology and physiology, Academic Press, New York, pp 43-78, https://doi.org/10.1016/b978-0-12472850-9.50008-6. 